\title{
Epidemiological Study of Syndromic Diagnosis Cases of HIV Positive Attending DVL OP in Government General Hospital Nizamabad Poola Ramachandra Rao* and S Surya Narayana
}

Government Medical College \& Hospital Nizamabad, India

\begin{abstract}
Sexually transmitted diseases (STD) consist of different group of endemic diseases of varying clinical presentation, characterized epidemiologically as sexually transmitted infections. Sexually transmitted diseases in individuals have far reaching health, social and economic consequences. Sexually transmitted infections are very important because of their potential complication and interaction with HIVIAIDS. Recognition of HIVISTI cases has tremendous contribution for targeted intervention in the hospital. By evaluating the HIVISTI cases it will be a signal to know the affected groups and major determinants. In this Paper, the study was conducted to evaluate the clinical, epidemiological and laboratory characteristics of the sexually transmitted diseases (STD) found in the government general Hospital, Nizamabad in the year 2013.
\end{abstract}

Keywords: HIV; HIV Transmission; Epidemiology; Diagnosis of HIV; Diagnosis of different diseases with HIV

\section{Introduction}

Sexually transmitted diseases (STD) consist of a group of endemic diseases of varying clinical presentation, characterized epidemiologically as sexually transmitted infections. Sexually transmitted diseases in different individuals with different age group may leads to Scabies, Genital Scabies, Lower abdominal Pain (LAP), Vagilo Cervical Discharge (VCD), Urethral Discharge (UD), Genital Ulcer Disease (GUD) - Genital Ulcer Disease Herpetic (GUDH) and Genital Ulcer Disease Non-Herpetic (GUDNH). HIV from sexual intercourse, the latter generally occurring within the context of sexual abuse. The objective of the present study is to evaluate the epidemiological, clinical and laboratory characteristics of different age groups with HIV Positive [1,2].

\section{Human Immunodeficiency Virus (HIV)}

The human immunodeficiency virus (HIV) is the cause of one of the most destructive human pandemics in recorded history. Acquired immune deficiency syndrome (AIDS) is a set of symptoms that occur in the final stage of an infection caused by the human immunodeficiency virus (HIV). AIDS occurs when the virus has destroyed the immune system, leaving the patient highly susceptible to other life threatening infections. People who are infected with HIV are referred to as being 'HIV positive', but they do not necessarily have any symptoms of disease. With the advent of new drug regimens it is now hoped that many HIV positive people may never reach the AIDS stage. HIV is an RNA virus known as a retrovirus. The HIV virion has a central core containing two identical RNA genomes and enzymes such as reverse transcriptase, protease and integrase. There is a protein capsid covered by a lipid bilayer envelope which contains glycoprotein spikes. There are two major strains of HIV. HIV-1 causes the majority of the infections worldwide and is more easily transmitted than the other strain HIV-2 [3-5].

\section{Retrovirus}

When cells make proteins they use their DNA as a template to make another nucleic acid called RNA. This process is called transcription. The information on the RNA is then used to assemble the sequence of polypeptides that make up a particular protein. This process is called translation.

\section{Reverse transcription}

Retroviruses are capable of carrying out transcription in reverse. They contain an enzyme called reverse transcriptase which transcribes the viral RNA into DNA. This DNA can then be inserted into the genome of the host cell, where it stays for the lifetime of the cell. The cell synthesizes viral RNA and proteins, allowing the virus to multiply inside the host cell.

\section{HIV Transmission}

The three main routes for HIV transmission are:

- Contaminated blood (for example between injecting drug users)

- Sex: vaginal, anal (and very rarely, oral)

- From mother to child (either in pregnancy, during birth or via breast milk)

- Worldwide, approximately $60 \%$ of new HIV infections are contracted through sex between men and women. The other cases are usually due to:

- Babies who acquire the virus from their mothers (10\%).

- $\quad$ Drug users sharing used needles (10\%).

- Sex between men (5-10\%).

In the early stages of the epidemic, some transmission occurred in health care settings, for example via infected blood for transfusion. This is now rare due to better screening and increased awareness.

*Corresponding author: Poola Ramachandra Rao, Assistant Professor in DVL, Government Medical College \& Hospital Nizamabad, Telangana, India, Tel: +910884 230087; E-mail: drnaickdora1970@gmail.com

Received October 09, 2015; Accepted November 30, 2015; Published December 08, 2015

Citation: Ramachandra Rao P, Narayana SS (2015) Epidemiological Study of Syndromic Diagnosis Cases of HIV Positive Attending DVL OP in Government General Hospital Nizamabad. J Trop Dis 4: 189. doi:10.4172/2329-891X.1000189

Copyright: (c) 2015 Ramachandra Rao P, et al. This is an open-access article distributed under the terms of the Creative Commons Attribution License, which permits unrestricted use, distribution, and reproduction in any medium, provided the original author and source are credited. 


\section{Epidemiology}

Identifying and understanding the risk factors associated with HIV acquisition and transmission, and the development and progression of AIDS in men, women, and adolescents are critical aspects in the fight against this disease. Using the epidemiological methods, scientists are able to address key scientific questions by studying and comparing the effects of HIV in different human populations. Scientific findings gathered from these epidemiological studies help to provide insight on how to prevent the spread of HIV and also improve the quality of life for those already infected [6-8]. The types of scientific investigation through epidemiological research include:

- $\quad$ Identifying the proportion of the population affected by HIV and the rate at which new infections are occurring.

- Describing the changing manifestations of the clinical and laboratory course of HIV infection, the changing frequency with which various complications occur, and the impact of therapy on HIV-related survival and clinical outcomes.

- Investigating the clinical course of HIV infection among people with other co-morbidities to better understand the natural and treated history of the disease in those with other chronic conditions.

- Studying the biological, clinical, and epidemiological characteristics of people who are at high risk for HIV infection but do not become infected and those who are long-term non-Progresso.

- The cause of GUD can be related to a number of factors, such as geographical area where sexual intercourse has taken place; socioeconomic factors; gender of sexual partners; number of partners; HIV status and local prevalence; drug use; commercial sex; and circumcision.

- GUD constitutes at most $5 \%$ of visits to physicians for a possible STI

- About 70 to $80 \%$ of genital ulcers are due to HSV-1 or HSV-2.

- Genital ulcers in sexually active persons can be associated with two or more pathogens.

- Women and men with GUD are at increased risk of acquiring and transmitting HIV.

- Chancroid has been sporadically associated with focal urban epidemics, particularly among cocaine users. Sex workers are the usual reservoir.

- Co-infection with HIV and hepatitis $\mathrm{C}$ virus are seen at a high rate. HIV infection increases the transmission of STI genital ulcers, and the reverse is also true.

- Scabies is caused by infection with Sarcoptesscabiei var Hominis (a mite parasitic to the horny layer of human skin). Major symptoms of this infection are skin lesions and itching arising from allergic reactions to the body, excretion and so forth of the parasite $[9,10]$.

\section{Materials and Methods}

Syndromic Diagnosis of Signs and symptoms of HIV were included in the study. An epidemiological study with a descriptive, exploratory approach was conducted by reviewing patients' charts and notification records, verifying the clinical, epidemiological and laboratory characteristics of sexually transmitted diseases in individuals and the patients' characteristics, including data on gender, age, race and place of birth. Etiological and syndromic diagnosis of HIV on 500 cases. Laboratory tests can help keep tabs on patient's health. Some of these tests will be done soon after patients are HIV positive [11-15]. Then depending on their immune status, whether they are on medication or not, and a variety of other factors, their provider will set up a schedule for them. Whether Patients have other diseases that are associated with HIV (tests for certain infections) [16,17].

The most common tests:

1) CD4 count: Immune system functioning condition

2) HIV viral load: Rapidly HIV is replicating, or multiplying,

3) Resistance test: Body functioning (tests on kidneys, liver, Cholesterol and blood cells)
4) Complete blood count
5) Blood chemistry tests
6) Fasting lipid profile
7) Tuberculosis test
8) STD screening
9) Hepatitis A, B, and C [18,19]

\section{Physical Examination}

A. Genital Regions:

1) Number of ulcers and pain:

- $\quad$ Solitary and painless: chancre

- $\quad$ Solitary and painful: trauma, Ca, TB, Behcet's disease

- $\quad$ Multiple and painful: primary herpes, chancroid, Behcet's disease.

- $\quad$ Multiple andpainless : secondary syphilis, recurrent herpes

2) Base of ulcer: indurated :

- $\quad$ Chancre, Ca

- $\quad$ Lymph nodes

\section{B. Extra-Genital Regions:}

They may give important clues to the diagnosis. E.g. palms and soles secondary syphilis, lips - fixed drug eruption, finger-webs scabies $[20,21]$.

\section{Laboratory Tests}

1) Dark-ground examination spirochetes - for primary and secondary syphilis

2) Serological tests -e.g. V.D.R.L., F.T.A., herpes simplex antibodies
3) Viral study
4) Biopsy - diagnostic in cancroids, $\mathrm{Ca}$
5) Screening for other S.T.D.S

\section{Management}



A. General management:
1) Saline dressing,
2) Analgesics,
3) Treatment of secondary infections

B. Specific treatment - depends on the etiological agents:

1) Genital herpes:

- Antivrialagents: e.g. Acyclovir, Famciclovir, Valaciclovir

- $\quad$ Counseling : male - depression is common; female - delivery screening for Ca cervix

2) Chancre and secondary syphilis:

- Penicillin: Procaine penicillin 1.2 mega UIMI $\times 10$ days, Benzathine penicillin 2.4 mega UIMI weekly $\times 3$ wks

- Tetracycline: Tetracycline $500 \mathrm{mg}$ quid $\times 2$ wks, Doxycycline $100 \mathrm{mg}$ bd $\times 2$ weeks

- $\quad$ Erythromycin $500 \mathrm{mg}$ qid $\times 2$ weeks

\section{3) Chancroid:}

- Multidose: Erythromycin500 mg qid $\times 2$ weeks, Cotrimoxazole $500 \mathrm{mg}$ bd $\times 2$ weeks, Ciprofloxacin $500 \mathrm{mgbd} \times 3$ days

- Single dose: Spectinomycin $2 \mathrm{G}$ IMI, Ofloxacin $400 \mathrm{mg}$, Ceftriaxone $250 \mathrm{mg}$ IMI

\section{Results}

The epidemiological Study of Syndromic Diagnosis of HIV Positive was conducted on 500 cases in the year 2013 in Government General Hospital, Nizamabad. Based on the symptoms, signs, 475Patients had HIV and also effected with different diseases in different cases [22,23].

Diseases effected to the percentage of Patients: (Tables 1-7)

1) $22 \%$ were effected with Scabies

2) $11 \%$ were effected with Genital Scabies

3) $20 \%$ were effected with GUDNH

4) $12 \%$ were effected with GUDH

5) $10 \%$ were effected with VCD

6) $10 \%$ were effected with UD

7) $10 \%$ were effected with LAP

Based on the symptoms, signs, laboratory investigations and diagnostic techniques, the Cases which are Diagnosed, Tabulated below and also graphically represented [24,25] (Charts 1-7).

\section{Discussion}

This study was conducted to determine the prevalence and determinants of HIV among Diagnosis of effective cases like who had HIV and also they suffered with Scabies, Genital Scabies, Lower abdominal Pain (LAP), Vagilo Cervical Discharge (VCD), Urethral Discharge (UD), Genital Ulcer Disease (GUD) - Genital Ulcer Disease

\begin{tabular}{|l|l|l|l|l|l|}
\hline S.No. & Sex & Age & HIV & VDRL & Diagnosis \\
\hline 1 & Male & 45 & Positive & Negative & Scabies \\
\hline 2 & Female & 30 & Negative & Negative & Scabies \\
\hline 3 & Female & 35 & Negative & Negative & Scabies \\
\hline 4 & Female & 28 & Negative & Negative & Scabies \\
\hline 5 & Female & 38 & Negative & Negative & Scabies \\
\hline 6 & Male & 55 & Negative & Negative & Scabies \\
\hline 7 & Female & 50 & Positive & Negative & Scabies \\
\hline 8 & Female & 32 & Positive & Negative & Scabies \\
\hline 9 & Male & 50 & Negative & Negative & Scabies \\
\hline 10 & Female & 25 & Positive & Negative & Scabies \\
\hline 11 & Male & 37 & Positive & Negative & Scabies \\
\hline 12 & Male & 32 & Positive & Negative & Scabies \\
\hline
\end{tabular}

Table 1: The patients were effected with Scabies.

\begin{tabular}{|c|c|c|c|c|c|}
\hline S. No. & Sex & Age & HIV & VDRL & Diagnosis \\
\hline 1 & Male & 45 & Positive & Negative & G S \\
\hline 2 & Female & 30 & Negative & Negative & G S \\
\hline 3 & Female & 35 & Positive & Negative & G S \\
\hline 4 & Female & 28 & Positive & Negative & G S \\
\hline 5 & Female & 38 & Negative & Negative & G S \\
\hline 6 & Male & 55 & Positive & Negative & G S \\
\hline 7 & Female & 50 & Negative & Negative & G S \\
\hline 8 & Female & 32 & Positive & Negative & G S \\
\hline 9 & Male & 50 & Positive & Negative & G S \\
\hline 10 & Female & 35 & Positive & Negative & G S \\
\hline
\end{tabular}

Table 2: The patients were effected with Genital Scabies.

\begin{tabular}{|c|c|c|c|c|c|}
\hline S. No. & Sex & Age & HIV & VDRL & Diagnosis \\
\hline 1 & Male & 28 & Positive & Negative & GUD- NH \\
\hline 2 & Female & 38 & Negative & Negative & GUD -NH \\
\hline 3 & Female & 26 & Negative & Negative & GUD -NH \\
\hline 4 & Female & 25 & Negative & Negative & GUD - NH \\
\hline 5 & Female & 30 & Negative & Negative & GUD - NH \\
\hline 6 & Male & 35 & Negative & Negative & GUD - NH \\
\hline 7 & Female & 38 & Positive & Negative & GUD - NH \\
\hline 8 & Female & 28 & Positive & Negative & GUD - NH \\
\hline 9 & Male & 32 & Positive & Negative & GUD $-\mathrm{NH}$ \\
\hline 10 & Female & 35 & Positive & Negative & GUD - NH \\
\hline
\end{tabular}

Table 3: The patients were effected withGenital Ulcer Disease Non-Herpetic (GUDNH)

\begin{tabular}{|c|c|c|c|c|c|}
\hline S. No. & Sex & Age & HIV & VDRL & Diagnosis \\
\hline 1 & Male & 32 & Positive & Negative & GUD - H \\
\hline 2 & Male & 35 & Negative & Negative & GUD - H \\
\hline 3 & Male & 35 & Positive & Negative & GUD - H \\
\hline 4 & Male & 38 & Positive & Negative & GUD - H \\
\hline 5 & Female & 28 & Negative & Negative & GUD - H \\
\hline 6 & Male & 28 & Negative & Negative & GUD - H \\
\hline 7 & Female & 38 & Positive & Negative & GUD - H \\
\hline 8 & Female & 26 & Positive & Negative & GUD - H \\
\hline 9 & Female & 25 & Positive & Negative & GUD - H \\
\hline 10 & Female & 30 & Positive & Negative & GUD - H \\
\hline
\end{tabular}

Table 4: The patients were effected with Genital Ulcer Disease Herpetic (GUDH) 
Citation: Ramachandra Rao P, Narayana SS (2015) Epidemiological Study of Syndromic Diagnosis Cases of HIV Positive Attending DVL OP in Government General Hospital Nizamabad. J Trop Dis 4: 189. doi:10.4172/2329-891X.1000189

\begin{tabular}{|c|c|c|c|c|c|}
\hline S. No. & Sex & Age & HIV & VDRL & Diagnosis \\
\hline 1 & Female & 30 & Negative & Negative & VCD \\
\hline 2 & Female & 32 & Negative & Negative & VCD \\
\hline 3 & Female & 58 & Positive & Negative & VCD \\
\hline 4 & Female & 45 & Positive & Negative & VCD \\
\hline 5 & Female & 40 & Positive & Negative & VCD \\
\hline 6 & Female & 28 & Positive & Negative & VCD \\
\hline 7 & Female & 26 & Positive & Negative & VCD \\
\hline 8 & Female & 38 & Positive & Negative & VCD \\
\hline 9 & Female & 26 & Positive & Negative & VCD \\
\hline 10 & Female & 35 & Positive & Negative & VCD \\
\hline
\end{tabular}

Table 5: The patients were effected with Vagilo Cervical Discharge (VCD)

\begin{tabular}{|c|c|c|c|c|c|}
\hline S. No. & Sex & Age & HIV & VDRL & Diagnosis \\
\hline 1 & Male & 35 & Positive & Negative & UD \\
\hline 2 & Male & 60 & Positive & Negative & UD \\
\hline 3 & Male & 48 & Positive & Negative & UD \\
\hline 4 & Male & 29 & Positive & Negative & UD \\
\hline 5 & Male & 35 & Positive & Negative & UD \\
\hline 6 & Male & 48 & Positive & Negative & UD \\
\hline 7 & Male & 60 & Positive & Negative & UD \\
\hline 8 & Male & 40 & Positive & Negative & UD \\
\hline 9 & Male & 55 & Positive & Negative & UD \\
\hline 10 & Male & 30 & Positive & Negative & UD \\
\hline
\end{tabular}

Table 6: The patients were effected with Urethral Discharge (UD)

\begin{tabular}{|c|c|c|c|c|c|}
\hline S.No. & Sex & Age & HIV & VDRL & Diagnosis \\
\hline 1 & Female & 35 & Positive & Negative & LAP \\
\hline 2 & Female & 25 & Positive & Negative & LAP \\
\hline 3 & Female & 45 & Positive & Negative & LAP \\
\hline 4 & Female & 40 & Positive & Negative & LAP \\
\hline 5 & Female & 28 & Positive & Negative & LAP \\
\hline 6 & Female & 26 & Positive & Negative & LAP \\
\hline 7 & Female & 38 & Positive & Negative & LAP \\
\hline 8 & Female & 26 & Positive & Negative & LAP \\
\hline 9 & Female & 35 & Positive & Negative & LAP \\
\hline 10 & Female & 32 & Positive & Negative & LAP \\
\hline
\end{tabular}

Table 7: The patients were effected with Lower abdominal Pain (LAP)

Herpetic (GUDH) and Genital Ulcer Disease Non-Herpetic (GUDNH) diseases in different age groups and different individuals [26, 27]. The total numbers of cases are 500, in which $95 \%$ are affected with HIV and also other diseases and cases were attended by the Government General Hospital, Nizamabad [28].

\section{Conclusion}

Diagnosis of HIV/STI cases in earlier Stage is important. By evaluating the $500 \mathrm{HIV} / \mathrm{STI}$ cases, $95 \%$ are affected with HIV and also other diseases. In this Paper, the study was conducted to diagnose the clinical, epidemiological characteristics of the sexually transmitted diseases (STD) and tested through labs, Patients were suffered with HIV and also they suffered with Scabies, Genital Scabies, Lower abdominal Pain (LAP), Vagilo Cervical Discharge (VCD), Urethral Discharge (UD), Genital Ulcer Disease (GUD) - Genital Ulcer Disease Herpetic

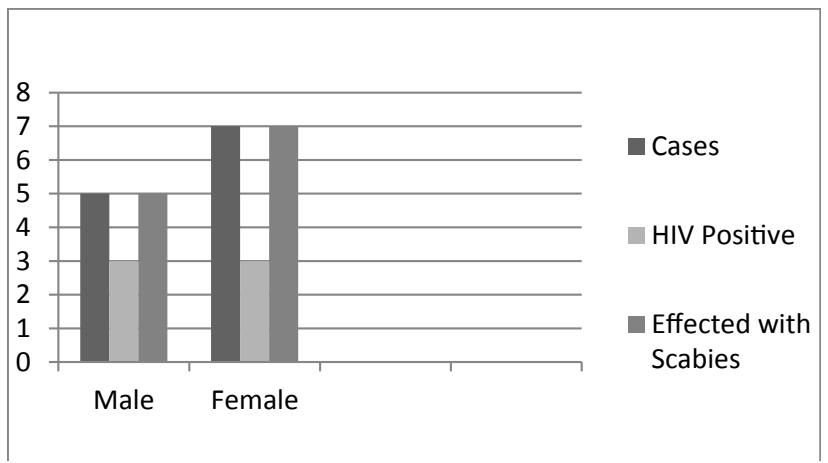

Chart 1: Effected with Scabies.

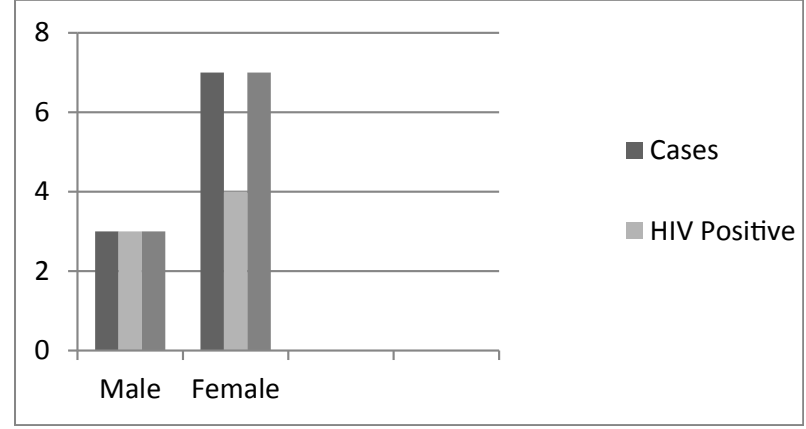

Chart 2: Effected with Genital Scabies (GS).

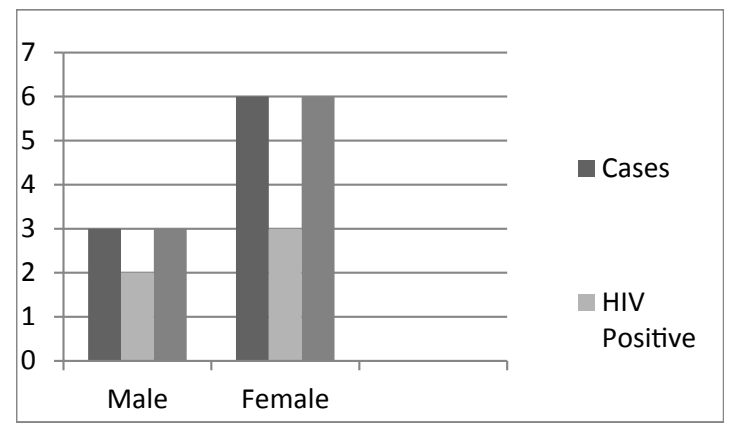

Chart 3: Effected with Genital Ulcer Disease Non-Herpetic (GUDNH)

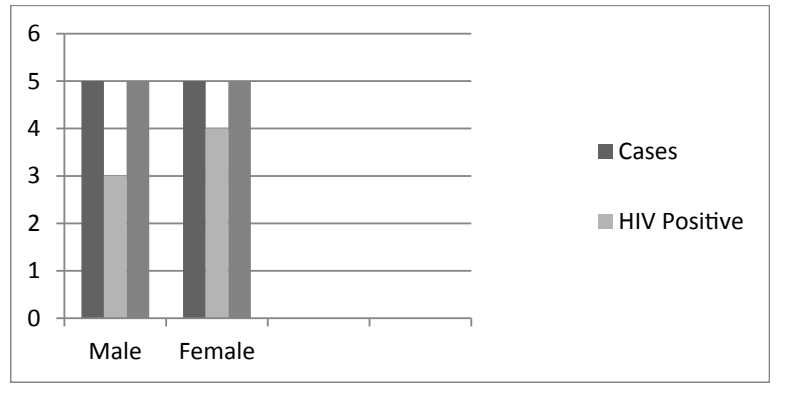

Chart 4: Effected with Genital Ulcer Disease Herpetic (GUDH). 
Citation: Ramachandra Rao P, Narayana SS (2015) Epidemiological Study of Syndromic Diagnosis Cases of HIV Positive Attending DVL OP in Government General Hospital Nizamabad. J Trop Dis 4: 189. doi:10.4172/2329-891X.1000189

Page 5 of 6

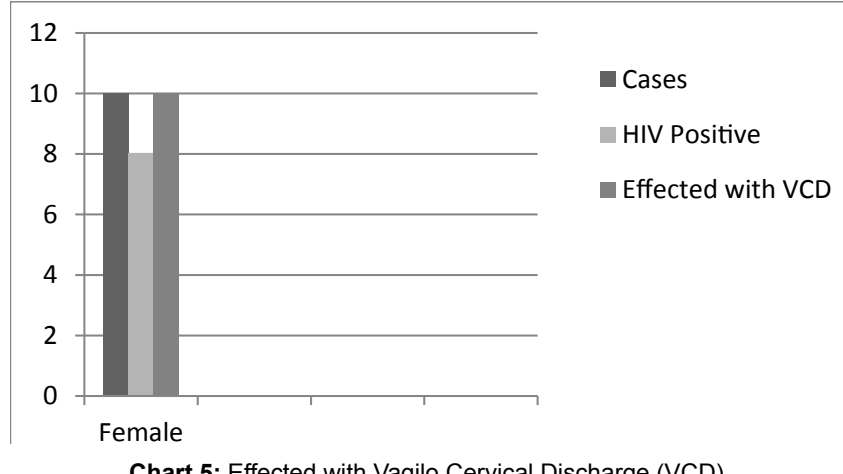

Chart 5: Effected with Vagilo Cervical Discharge (VCD).

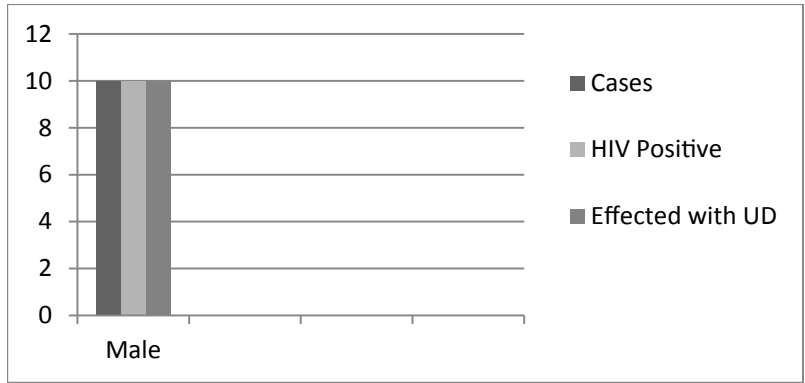

Chart 6: Effected with Urethral Discharge (UD).

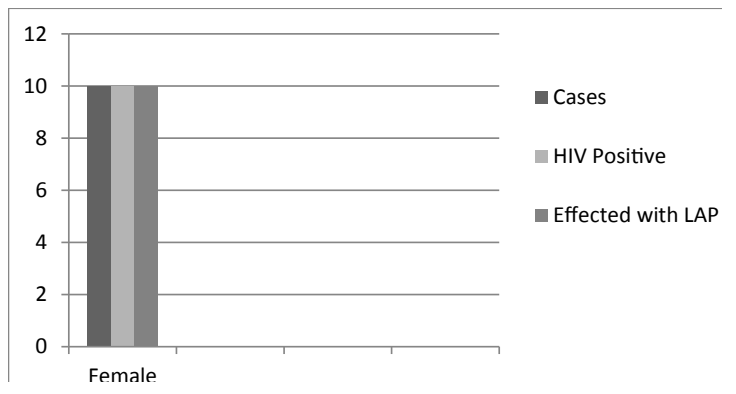

Chart 7: Effected with Lower abdominal Pain (LAP).

(GUDH) and Genital Ulcer Disease Non-Herpetic (GUDNH) diseases in the government general Hospital, Nizamabad in 2013.Furthermore, public health intervention on consistent condom use and partner notification and referral should be given due emphasis targeted to the most at risk population.

\section{References}

1. Steen R, Wi TE, Kamali A, Ndowa F (2009) Control of Sexually transmitted infections and prevention of HIV transmission:Mending a fractured paradigm. BULL World Health Organ 87: 858-865.

2. Cuadros DF, Crowley PH, Augustine B, Stewart SL, García-Ramos G (2011) Effect of variable transmission rate on the dynamics of HIV in Sub Sharan Africa. BMC infectious Disease 11: 216

3. Federal Ministry of Health (2006) Syndromic Management of Sexually Transmitted Infections HIV Prevention and Control office, Ethiopia.

4. Chow EP, Wilson DP, Zhang L (2011) HIV and syphilis co-infection increasing among men who have sex with men in China: a systematic review and metaanalysis. PLoS One 6: e22768.
5. Ward H, Rönn M (2010) Contribution of sexually transmitted infections to the sexual transmission of HIV. Curr Opin HIV AIDS 5: 305-310.

6. Zhang G, Wong M, Yi P, Xu J, Li B, et al. (2010) HIV-1 and STIs prevalence and risk factors of miners in mining districts of Yunnan, China. J Acquir Immune Defic Syndr 53 Suppl 1: S54-60.

7. Xu JJ, Reilly KH, Lu CM, Ma N, Zhang M, et al. (2011) A cross-sectional study of HIV and syphilis infections among male students who have sex with men (MSM) in northeast China: implications for implementing HIV screening and intervention programs. BMC Public Health 11: 287.

8. Khan MS, Unemo M, Zaman S, Lundborg CS (2011) HIV, STI prevalence and risk behaviours among women selling sex in Lahore, Pakistan. BMC Infect Dis 11: 119 .

9. Clark JL, Konda KA, Munayco CV, Pún M, Lescano AG, et al. (2008) Prevalence of HIV, herpes simplex virus-2, and syphilis in male sex partners of pregnant women in Peru. BMC Public Health 8: 65.

10. Månsson F, Camara C, Biai A, Monteiro M, da Silva ZJ, et al. (2010) High prevalence of HIV-1,HIV-2 and other sexually transmitted infections among women attending two sexual health clinics in Bissau, Guinea-Bissau. West Africa Int J STD AIDS September 21: 631-635.

11. Vu Thuong N, Van Nghia K, Phuc Hau T, Thanh Long N, Thi Bao Van C, et al (2007) Impact of a community sexually transmitted infection/HIV intervention project on female sex workers in five border provinces of Vietnam. Sex Transm Infect 83: 376-382

12. Lule G, Behets FM, Hoffman IF, Dallabetta G, Hamilton HA, et al. (1994) STD/ HIV control in Malawi and the search for affordable and effective urethritis therapy: a first field evaluation. Genitourin Med 70: 384-388.

13. Patterson TL, Goldenberg S, Gallardo M, Lozada R, Semple SJ, et al. (2009) Correlates of HIV, sexually transmitted infections, and associated high-risk behaviors among male clients of female sex workers in Tijuana, Mexico. AIDS 23: $1765-1771$.

14. Weaver MR, Myaya M, Disasi K, Regoeng M, Matumo HN, et al. (2008) Routine HIV testing in the context of syndromic management of sexually transmitted infections: outcomes of the first phase of a training programme in Botswana Sex Transm Infect 84: 259-264.

15. Desai VK, Kosambiya JK, Thakar HG, Umrigar DD, Khandwala BR, et al. (2003) Prevalence of Sexually transmitted infections and performance of ST syndromes against etiology diagnosis, in female sex workers of red light area in Surat, India. Sex transm Infect 79: 111-115.

16. Kehinde AO, Lawoyin TO (2005) Prevalence of STI/HIV co-infections among special treatment clinic attendees in Ibadan, Nigeria. J R Soc Promot Health 125: $186-190$

17. Wawer MJ, Sewankambo NK, Serwadda D, Quinn TC, Paxton LA, et al. (1999) Rakai Project Study Group Control of sexually transmitted diseases for AIDS prevention in Uganda: a randomized community trial. Lancet 353: 525-535.

18. Khadija IYM, Bjorg EO, Mecky IM, Knut F, Lars H (2008) HIV-1,HSV-2 and Syphilis among pregnant women in a rural area of Tanzania: Prevalence and risk factors. BMC infectious diseases 8: 75.

19. Girma A, Geyid A, Mekonnen Z (2003) Validation of the Syndromic Algorithm Approach for Management of Sexually Transmitted Infections (STIs) in Ethiopia. EHNRI-CDC Collaborative research.

20. Uchikawa K (2001) Biology of Sarcoptesscabiei. Infect Agents Surveillance Report 22: 246-247.

21. Jabeen N, Soomro U (2001) Bacterial vaginosis. Gynaecologist 5: 56-67.

22. Sahoo B, Bhandari H, Sharma M, Malhotra S, Sawhney H, et al. (2000) Role of the male partner in the lower genitourinary tract infection of female. Indian $\mathrm{J}$ Med Res 112: 9-14.

23. Vermeulen GM, van Zwet AA, Bruinse HW (2001) Changes in the vaginal flora after two percent clindamycin vaginal cream in women at high risk of spontaneous preterm birth. BJOG 108: 697-700.

24. Fry J (1979) Common diseases, their nature, incidence and care 2ndedition MTP Press, Lancaster, England.

25. Hart G (1993) Factors associated with trichomoniasis, candidiasis and bacterial vaginosis. Int J STD AIDS 4: 21-25.

26. Gertig DM, Kapiga SH, Shao JF, Hunter DJ (1997) Risk factors for sexually 
Citation: Ramachandra Rao P, Narayana SS (2015) Epidemiological Study of Syndromic Diagnosis Cases of HIV Positive Attending DVL OP in Government General Hospital Nizamabad. J Trop Dis 4: 189. doi:10.4172/2329-891X.1000189

Page 6 of 6

transmitted diseases among women attending family planning clinics in Dares-Salaam, Tanzania. Genitourin Med 73: 39-43.

27. Collee JG, Duguid JP, Fraser AG, Marmion BP, Simmons A (1996) Laboratory strategy in the diagnosis of infective syndromes (14 $14^{\text {th }}$ edtn), In: Collee JG,
Fraser AG, Marmion BP, Simmons A (edts) Mackie \& McCartney practical medical microbiology, Churchill Livingstone, New York.

28. Peipert JF, Montagno AB, Cooper AS, Sung CJ (1997) Bacterial vaginosis as a risk factor for upper genital tract infection. Am J Obstet Gynecol 177: 11841187. 